\title{
ENSO Normals: A New U.S. Climate Normals Product Conditioned by ENSO Phase and Intensity and Accounting for Secular Trends
}

\author{
ANTHONY ARGUEZ \\ NOAA/National Centers for Environmental Information, Asheville, North Carolina \\ ANAND INAMDAR \\ Cooperative Institute for Climate and Satellites-North Carolina, North Carolina State University, \\ Asheville, North Carolina \\ Michael A. PALECKI \\ NOAA/National Centers for Environmental Information, Asheville, North Carolina \\ CARL J. SCHRECK \\ Cooperative Institute for Climate and Satellites-North Carolina, North Carolina State University, \\ Asheville, North Carolina \\ Alisa H. Young \\ NOAA/National Centers for Environmental Information, Boulder, Colorado
}

(Manuscript received 24 September 2018, in final form 30 April 2019)

\begin{abstract}
Climate normals are traditionally calculated every decade as the average values over a period of time, often 30 years. Such an approach assumes a stationary climate, with several alternatives recently introduced to account for monotonic climate change. However, these methods fail to account for interannual climate variability [e.g., El Niño-Southern Oscillation (ENSO)] that systematically alters the background state of the climate similar to climate change. These effects and their uncertainties are well established, but they are not reflected in any readily available climate normals datasets. A new high-resolution set of normals is derived for the contiguous United States that accounts for ENSO and uses the optimal climate normal (OCN) - a 10-yr (15 yr) running average for temperature (precipitation) — to account for climate change. Anomalies are calculated by subtracting the running means and then compositing into 5 ENSO phase and intensity categories: Strong La Niña, Weak La Niña, Neutral, Weak El Niño, and Strong El Niño. Seasonal composites are produced for each of the five phases. The ENSO normals are the sum of these composites with the OCN for a given month. The result is five sets of normals, one for each phase, which users may consult with respect to anticipated ENSO outcomes. While well-established ENSO patterns are found in most cases, a distinct east-west temperature anomaly pattern emerges for Weak El Niño events. This new product can assist stakeholders in planning for a broad array of possible ENSO impacts in a changing climate.
\end{abstract}

\section{Introduction}

Member countries of the World Meteorological Organization (WMO) have been producing 30-yr climate normals for more than 75 years under mandated regulations, with many countries recomputing 30-yr

Corresponding author: Anthony Arguez, anthony.arguez@noaa.gov climate normals every 10 years (Arguez and Vose 2011). However, U.S. climate has experienced very rapid and dramatic changes during the last 30 years, and thus it has been suggested that the 30-yr normals are of limited use for design, planning, and decision-making purposes (Livezey et al. 2007; Arguez and Vose 2011; Wilks and Livezey 2013). New recommendations were made to the WMO and national climate services to formulate new 
policies for changing climate normals, as well as for the National Oceanic and Atmospheric Administration (NOAA) to initiate a program for improved estimates and forecasts of official U.S. normals. The latter would include an operational implementation of a system blending trend analysis, optimal climate normals $(\mathrm{OCN}$; Huang et al. 1996; a variable-length normal) or a quasilinear fit, and separating the effects of important modes of interannual climate variability like El Niño-Southern Oscillation (ENSO). Following these recommendations, a workshop was held in Asheville, North Carolina, in 2012 (Arguez et al. 2013) with a total of 50 participants representing the energy industry, state regulators, and federal climate scientists to discuss the industry's need for alternatives to the traditional 30-yr climate normals. Consensus emerged from workshop participants that such alternatives were indeed necessary. Additional requirements gathered from load forecasters and agricultural interests suggested that climate normals conditioned by ENSO phases would also be readily used by industry stakeholders.

Many studies over the past three decades have documented relationships between ENSO phase and important climate phenomena, including temperature and precipitation patterns in North America (e.g., Horel and Wallace 1981; van Loon and Madden 1981; Rasmusson and Carpenter 1982; Ropelewski and Halpert 1986, 1987, 1989). Most studies have relied on composites keyed to a particular index such as the Southern Oscillation index (SOI) or the Niño-3.4 index of sea surface temperature (SST) to highlight regions of strong, consistent relationships to the ENSO cycle (e.g., Ropelewski and Halpert 1996).

NOAA's Climate Prediction Center (CPC) issues official seasonal forecasts for U.S. temperature and precipitation for leads out to 12.5 months. Statistical input for the seasonal forecasts is obtained from OCN and canonical correlation analysis (CCA; e.g., Barnston and Ropelewski 1992), while dynamical input comes from the National Centers for Environmental Prediction (NCEP) coupled model (Ji et al. 1998). The skill of CPC forecasts is primarily driven by climate change (especially for temperature) and ENSO (especially for precipitation). However, the ENSO influences on temperature and precipitation trends over the United States have been changing (Mo 2010). Comparison of the early period (1915-60) versus recent period (1962-2006) composites suggests the dipole in temperature between the north and south during warm ENSO winters is weakening. Recently eight different anomalous SST patterns have been identified (Johnson 2013; Guo et al. 2017) using a neural-network-based clustering technique known as self-organizing maps (SOM).
The impact of each of the SOM SST patterns on wintermean temperature and precipitation anomalies over North America reveal distinctive teleconnection patterns associated with different flavors of ENSO conditions. Although the strength of any two individual ENSO events may be similar, each ENSO event is unique in character. For instance, the recent 2015/16 extreme El Niño event was comparable in strength to the 1997/98 extreme event, and yet their impacts on temperature and precipitation patterns over the U.S. mainland were different (Paek et al. 2017). The two El Niño events differed in their SST evolution (central Pacific versus eastern Pacific) and the retreat of the anomalous SST pattern during the decay phase. This shows that characterizing the relationship between ENSO events, associated climate teleconnections, and regional seasonal climate prediction can be challenging, and highlights the importance of understanding the distribution of ENSO phase impacts rather than relying solely on mean composites.

In the present investigation, we document our approach for calculating "ENSO normals" of temperature and precipitation for the contiguous United States (CONUS) in a manner that accounts for background climate change trends. By providing this product at a $\sim 5-\mathrm{km}$ resolution and including quantile values in addition to mean composites, we hope to empower stakeholders to better prepare for forecasted ENSO conditions for their areas of interest.

\section{Data}

\section{a. $O N I$}

The state of ENSO can be determined in a number of ways, using sea level pressure (SLP; Walker and Bliss 1932, 1937), SST (Rasmusson and Carpenter 1982), outgoing longwave radiation (OLR; Chiodi and Harrison 2013), or a multivariate ENSO index (MEI; Wolter and Timlin 2011). The most commonly used index is Niño-3.4 (Trenberth 1997), the average SST anomaly covering the region $5^{\circ} \mathrm{S}-5^{\circ} \mathrm{N}, 120^{\circ}-170^{\circ} \mathrm{W}$ (Barnston et al. 1997). To filter out month-to-month variability, $\mathrm{CPC}$ uses the oceanic Niño index (ONI): a three-month running average of Niño-3.4. The ONI as produced by CPC is based on monthly anomalies derived using 30 -yr base periods centered on the beginning year of each $5-\mathrm{yr}$ period. For example, the anomalies for each month in the 1996-2000 period are calculated using the 30-yr base period 1981-2010. As years move toward the present, the latest available base period, 1985-2015, is applied until the next update cycle in 2021. In this study, the 1951-2017 ONI values used are those calculated by 
TABLE 1. ONI thresholds $\left({ }^{\circ} \mathrm{C}\right)$ used to identify ENSO categories of Strong La Niña $(-2)$, Weak La Niña (-1), Weak El Niño (1), and Strong El Niño (2).

\begin{tabular}{|c|c|c|c|c|c|c|c|c|c|c|c|c|}
\hline ENSO category & DJF & JFM & FMA & MAM & AMJ & MJJ & JJA & JAS & ASO & SON & OND & NDJ \\
\hline-2 & -0.87 & -0.75 & -0.64 & -0.52 & -0.57 & -0.57 & -0.56 & -0.66 & -0.80 & -0.81 & -0.95 & -0.98 \\
\hline-1 & -0.51 & -0.44 & -0.26 & -0.29 & -0.26 & -0.29 & -0.30 & -0.29 & -0.36 & -0.40 & -0.49 & -0.51 \\
\hline 1 & 0.55 & 0.39 & 0.28 & 0.29 & 0.32 & 0.32 & 0.31 & 0.34 & 0.39 & 0.44 & 0.54 & 0.63 \\
\hline 2 & 1.03 & 0.69 & 0.59 & 0.66 & 0.64 & 0.65 & 0.72 & 0.70 & 0.79 & 0.95 & 1.19 & 1.13 \\
\hline
\end{tabular}

CPC (2018) in the manner described using the latest Extended Reconstruction Sea Surface Temperature, version 5 (ERSSTv5; Huang et al. 2017). The operationally updated data, reported to the hundredths place, is accessible from the CPC website. ${ }^{1}$

\section{b. Gridded monthly climate data}

Many efforts to generate composite patterns of climate anomalies associated with ENSO have begun with coarse-resolution monthly gridded data formed from one of several national or global station networks. The CPC El Niño and La Niña temperature composites (CPC 2012), for instance, are based on a $0.5^{\circ} \times 0.5^{\circ}$ latitude-longitude-resolution gridded dataset (Fan and van den Dool 2008). One exception to this was the effort of Dourte et al. (2017) to construct ENSO composite anomalies for agricultural applications (AgroClimate 2016) using the approximately 4-km-resolution ParameterElevation Regressions on Independent Slopes Model (PRISM) dataset (Daly et al. 2008). In their approach, gridded anomalies were calculated using a base period of 1950-2013 and then combined into El Niño, Neutral, and La Niña composites by month based on the MEI determination of the ENSO state. Maps of temperature and precipitation anomalies are provided by month and ENSO state and combined with the 1950-2013 averages for applications requiring temperature and precipitation values.

This paper describes an improved process for generating ENSO normals for the United States, starting with the treatment of the precipitation and temperature data inputs. We utilize nClimGrid, a $\sim 5 \mathrm{~km} \times \sim 5 \mathrm{~km}$ monthly gridded climate dataset developed by Vose et al. (2014). The temperature grids are based on over 10000 stations and the precipitation grids on over 14000 stations that have been subject to advanced quality control procedures in the Global Historical Climatology Network-Daily (GHCN-Daily) dataset (Durre et al. 2010; Menne et al. 2012). The maximum and minimum temperature station records were also subject to pairwise homogenization (Menne and Williams 2009).

\footnotetext{
${ }^{1}$ http://www.cpc.ncep.noaa.gov/data/indices/oni.ascii.txt.
}

Climatologically aided interpolation for each month and data type was based on 1981-2010 normals grids combined with monthly anomaly fields (Vose et al. 2014). The nClimGrid dataset ${ }^{2}$ is available from NOAA's National Centers for Environmental Information.

\section{Methodology}

CPC defines ENSO events as five consecutive 3-month seasons [e.g., October-December (OND), NovemberJanuary (NDJ), December-February (DJF), JanuaryMarch (JFM), February-April (FMA)] during which ONI exceeds $+0.5^{\circ} \mathrm{C}$ for El Niño and $-0.5^{\circ} \mathrm{C}$ for $\mathrm{La}$ Niña. Our approach is inspired by theirs but with some key differences. Many studies note differences in impacts between Strong and Weak events, so we chose to stratify ENSO into five groups: Strong La Niña, Weak La Niña, Neutral, Weak El Niño, and Strong El Niño.

For each overlapping 3-month season, we use CPC's ONI values to stratify ENSO phase and intensity using a terciles approach. In this method, El Niño events are defined as the top one-third of the ONI distribution for a given season, La Niña events are defined by the bottom one-third, and Neutral events are defined as the middle third. El Niño and La Niña events are further delineated for intensity whereby the warmest half of all El Niño events for that season (i.e., the warmest sextile overall) are designated as Strong events and the coolest half are designated as Weak El Niños. In a likewise manner, the coolest half of all La Niña events are diagnosed as Strong La Niñas and the warmest half are diagnosed as Weak La Niñas. The corresponding thresholds are shown in Table 1 , and differ from the fixed $0.5^{\circ} \mathrm{C}$ threshold used by CPC to define ENSO events. After evaluating the instantaneous ENSO phase for each season, we adopt the CPC 5-month persistence criterion to arrive at designations of Strong El Niño (2), Weak El Niño (1), Neutral (0), Weak La Niña (-1), and Strong La Niña $(-2)$ events. For individual seasons in which the 5-month persistence criterion is not met, Strong events are

\footnotetext{
${ }^{2} \mathrm{ftp} / / / \mathrm{ftp}$.ncdc.noaa.gov/pub/data/climgrid/.
} 

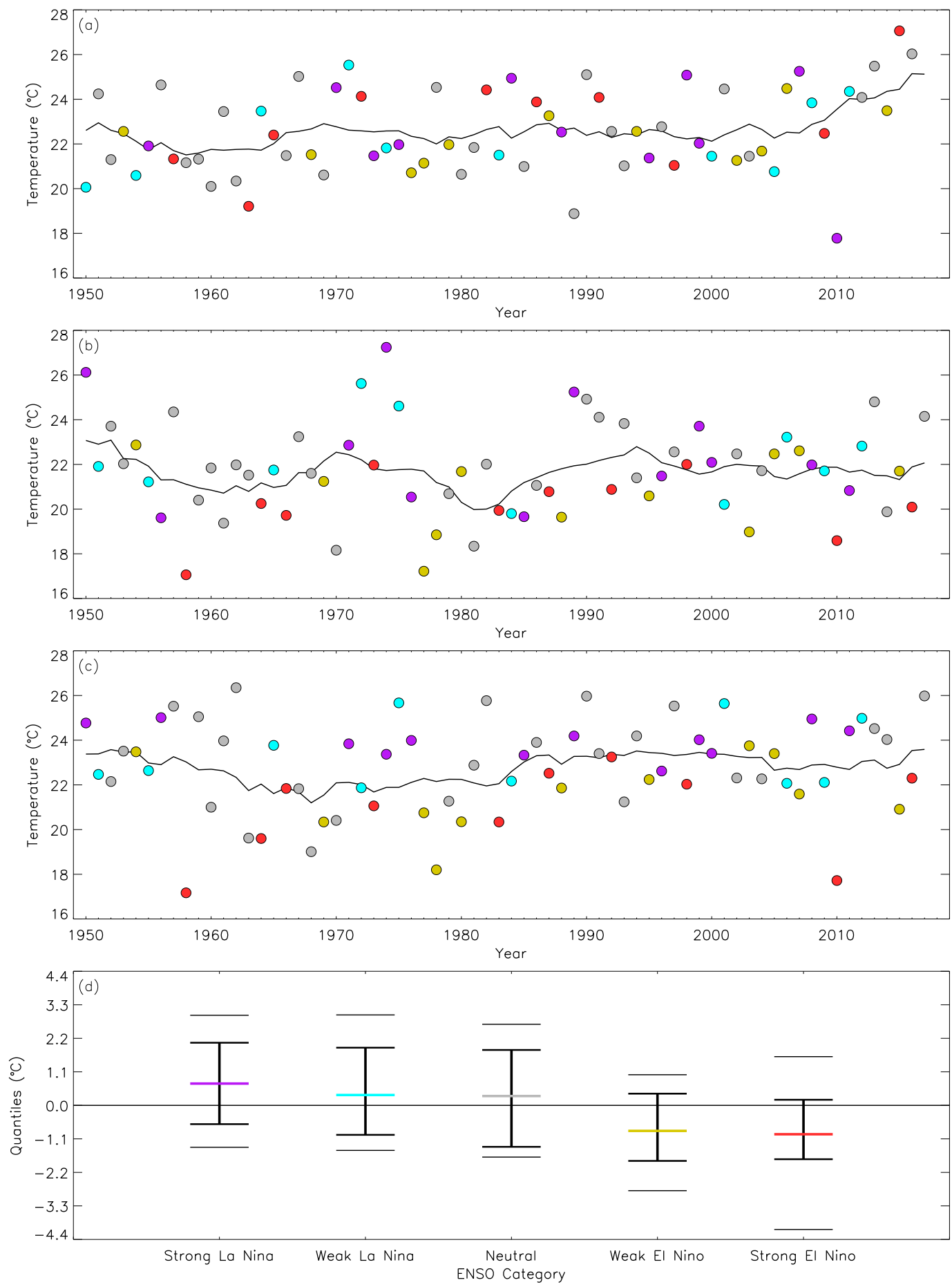

FIG. 1. Mean monthly maximum temperatures $\left({ }^{\circ} \mathrm{C}\right)$ for Orlando $\left(28.5208^{\circ} \mathrm{N}, 81.3958^{\circ} \mathrm{W}\right)$ from 1951 to 2017 for (a) December, (b) January, and (c) February. The color of each circle indicates the ENSO phase of the corresponding DJF season: Strong La Niña (purple), Weak La Niña (blue), Neutral (gray), Weak El Niño (yellow), and Strong El Niño (red). The solid black curve indicates the running 11-yr average with estimates for 2013-17 computed following Mann (2004). (d) Associated quantile values $\left({ }^{\circ} \mathrm{C}\right.$ ) of January temperature anomalies for each ENSO phase. Solid (bold) horizontal black lines indicate the 10th and 90th (25th and 75th) quantiles. The composite mean is shown as the middle horizontal bar color-coded as in (a)-(c). 


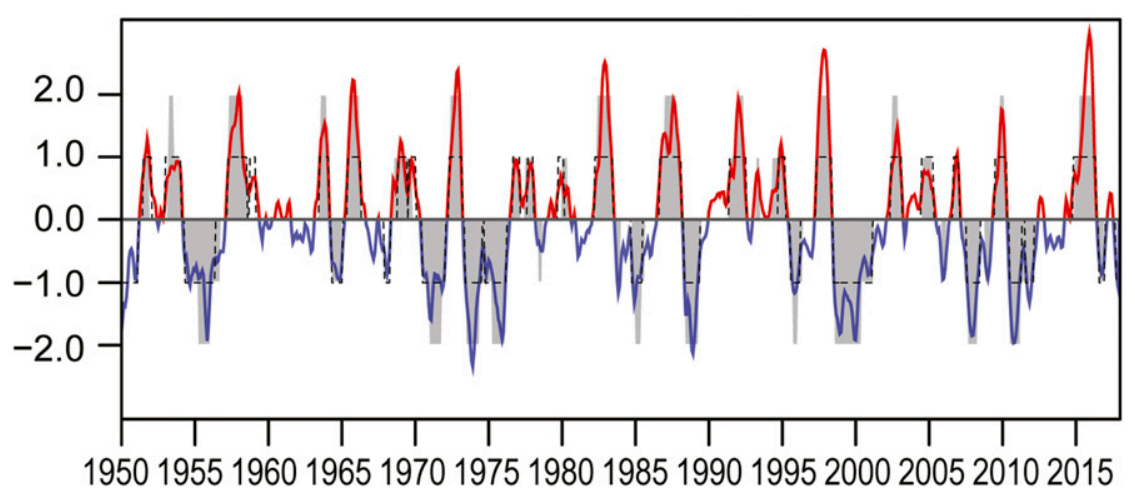

FIG. 2. Seasonal ONI (positive in red, negative in blue) and ENSO classifications. CPC ENSO events are shown by black dashed boxes. Classifications for the current study are shaded in gray: Strong La Niña (-2), Weak La Niña (-1), Neutral (0), Weak El Niño (1), and Strong El Niño (2).

downgraded to Weak (provided they meet the persistence criterion for the Weak threshold) and Weak events are downgraded to Neutral.

A drawback to most past efforts to generate ENSO composites or climatologies is the use of climate normal base periods that are static. Over large areas of the United States, precipitation and especially temperature have been trending in recent decades, and these trends may distort the patterns of resulting ENSO climatologies for current times. Therefore, we calculate "detrended" anomalies via a variant of CPC's OCN method using 11-yr moving windows for both maximum and minimum temperature and 15 -yr moving windows for precipitation. Our approach differs from the operational CPC method in that our anomalies are centered on each target year in the computation, whereas CPC uses an OCN that is updated every 5 years without extending the time series. To calculate centered values in the earlier part of the record, we utilize nClimGrid data from the 1940s to complete the convolution. For the most recent period, anomalies are determined using the Mann (2004) approach, extending each gridcell-specific series forward in time according to constraints for minimum norm, slope, or roughness and then selecting the method that minimizes the resulting root-mean-square error. To avoid generation of negative precipitation values, the roughness method is not included for precipitation analyses.

The detrended anomalies are composited for each of the five ENSO categories for each grid point, month, and variable. Temperature composites are reported in degrees Celsius, whereas precipitation composites are computed in percent of normal space and subsequently reported in percent deviations from the corresponding OCN value. Note that we report composites for each month, not season. For example, we utilize detrended
December, January, and February anomalies to estimate the January composites (see Figs. 1a-c for an illustration for Orlando, Florida). Furthermore, in addition to the mean composite, we also report the 10th, 25th, 75th, and 90th quantiles (see Fig. 1d) of the distribution for each set of monthly anomalies conditioned by ENSO category. Therefore, our results capture the expectation and a broad range of possible outcomes for a monthly anomaly for a particular ENSO category. Last, to arrive at the ENSO normal, the monthly temperature (precipitation) OCN value is added to (scaled by) the corresponding composite value.

\section{Results}

The seasonal ENSO categories from 1950 through 2017 as determined by the proposed tercile method are shown in Fig. 2. La Niña, Neutral, and El Niño events comprise $31 \%, 38 \%$, and $31 \%$, respectively, of all overlapping 3-month seasons (see Table 2). The counts for La Niña and El Niño are further divided equitably between Weak and Strong events. The results are qualitatively similar to CPC's fixed $0.5^{\circ} \mathrm{C}$ threshold, with the main difference being that the tercile method produces somewhat fewer Neutral seasons and more La Niña/El Niño seasons. Both methods have higher percentages of El Niño and La Niña events in the boreal fall and winter than the spring and summer, but that difference is larger with CPC's fixed threshold.

\section{a. DJF composites}

The DJF Tmax composites (Fig. 3) reveal the wellknown ENSO impacts for the Strong phases, with a sharp north-south or northwest-southeast gradient 
TABLE 2. Counts of ENSO events by overlapping 3-month season using our terciles approach and the CPC method. For the terciles approach, the events are categorized as Strong La Niña (-2), Weak La Niña (-1), Neutral (0), Weak El Niño (1), and Strong El Niño (2). For the CPC method, LN = La Niña, $\mathrm{N}=$ Neutral, and EN = El Niño.

\begin{tabular}{|c|c|c|c|c|c|c|c|c|c|c|c|c|c|}
\hline Type & DJF & JFM & FMA & MAM & AMJ & MJJ & JJA & JAS & ASO & SON & OND & NDJ & Total \\
\hline \multicolumn{14}{|c|}{ Terciles approach } \\
\hline-2 & 12 & 12 & 12 & 11 & 11 & 11 & 8 & 9 & 10 & 10 & 10 & 11 & 127 \\
\hline-1 & 10 & 7 & 6 & 8 & 9 & 10 & 14 & 12 & 13 & 13 & 13 & 12 & 127 \\
\hline 0 & 25 & 28 & 31 & 30 & 27 & 26 & 25 & 26 & 23 & 24 & 23 & 23 & 311 \\
\hline 1 & 11 & 12 & 9 & 9 & 11 & 10 & 11 & 11 & 13 & 11 & 11 & 11 & 130 \\
\hline 2 & 10 & 9 & 10 & 10 & 10 & 11 & 10 & 10 & 9 & 10 & 11 & 11 & 121 \\
\hline \multicolumn{14}{|c|}{ CPC method } \\
\hline $\mathrm{LN}$ & 21 & 18 & 17 & 13 & 16 & 15 & 18 & 18 & 18 & 20 & 22 & 22 & 218 \\
\hline $\mathrm{N}$ & 23 & 29 & 37 & 43 & 37 & 38 & 35 & 35 & 30 & 26 & 22 & 22 & 377 \\
\hline EN & 24 & 21 & 14 & 12 & 15 & 15 & 15 & 15 & 20 & 22 & 24 & 24 & 221 \\
\hline
\end{tabular}

across CONUS, with cooler conditions in the northern (southern) tier during La Niña (El Niño). The Weak El Niño case shows a marked east-west gradient, with cool anomalies in the east and warm anomalies in the west. Notably, the spatial correlation coefficient between the Strong and Weak El Niño composites is
0.01. The Weak La Niña composite pattern, on the other hand, reveals a largely statistically insignificant signal, but one that is anticorrelated with the Weak El Niño composites $(r=-0.75)$ and positively correlated with the Strong La Niña impacts $(r=0.70)$. The DJF Tmin composites (Fig. 4) show a similar
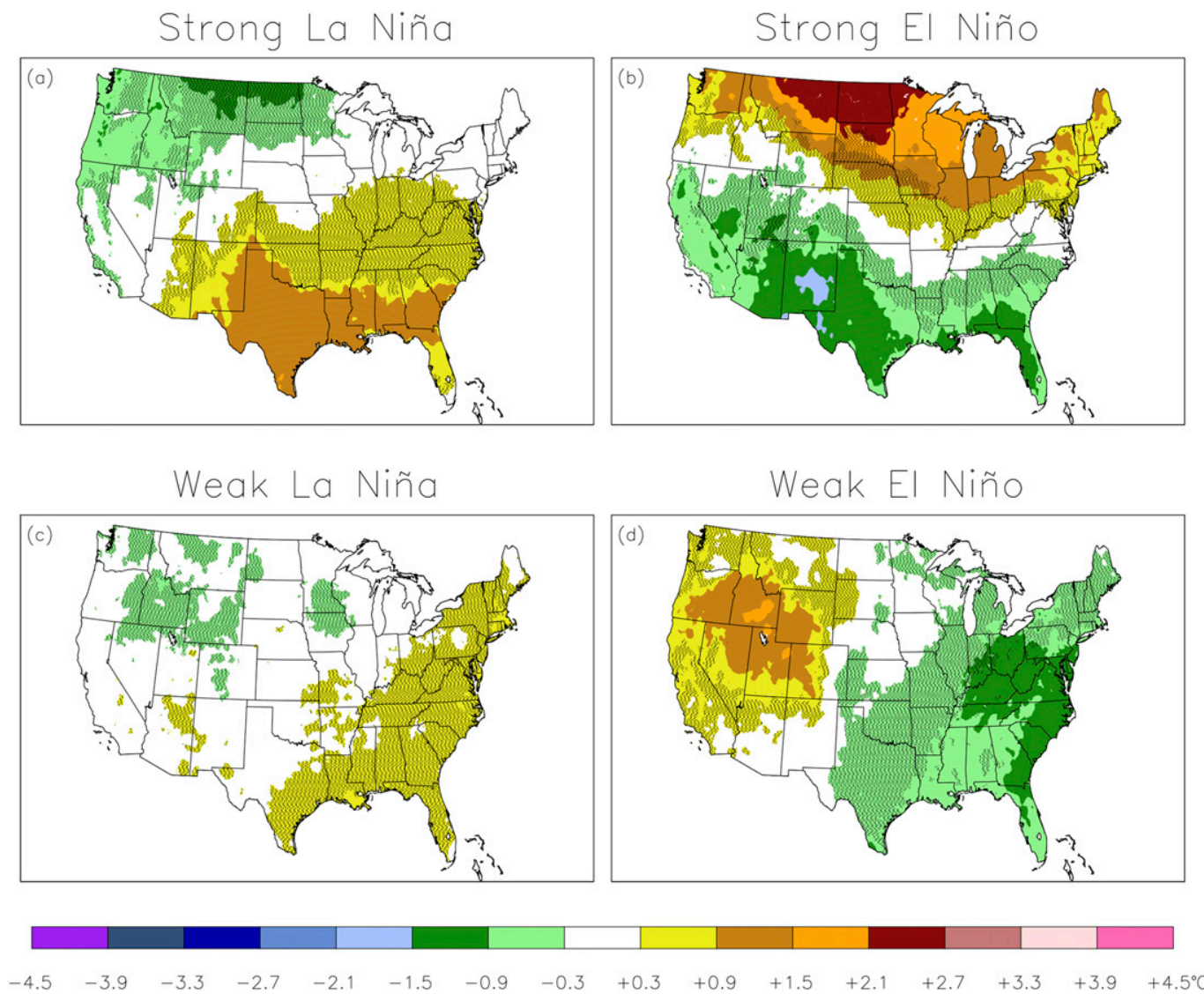

FIG. 3. ENSO composites of DJF mean monthly maximum temperature for (a) Strong La Niña, (b) Strong El Niño, (c) Weak La Niña, and (d) Weak El Niño. Hatching indicates values outside of the near-zero interval (white) that are not significantly different from zero at $90 \%$ confidence. 

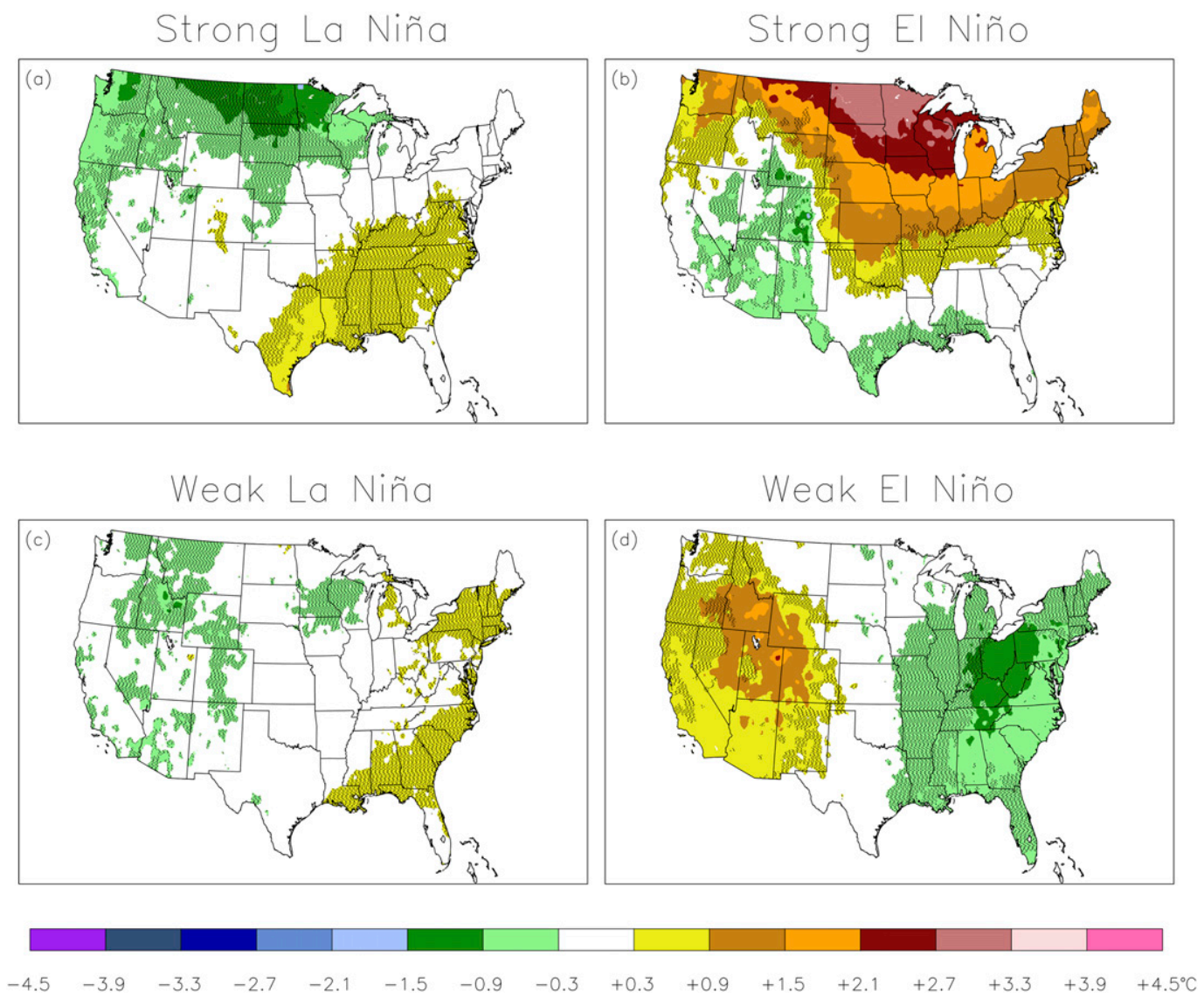

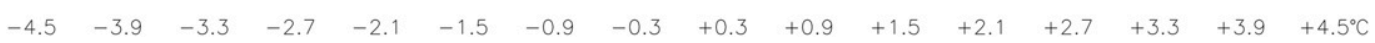

FIG. 4. As in Fig. 3, but for DJF mean monthly minimum temperature.

scenario, including the east-west signal for the Weak El Niño composites, although the Strong El Niño warm anomalies are considerably more prominent than the cool anomalies.

The DJF precipitation (Prcp) composites (Fig. 5) offers a more striking contrast between Strong La Niña and Strong El Niño conditions $(r=-0.83)$ with dry (wet) conditions across the southern tier of CONUS during Strong La Niña (Strong El Niño) events. The Weak cases are also anticorrelated with each other $(r=-0.72)$. Interestingly, the Weak and Strong La Niña composites are moderately well correlated $(r=0.61)$ while the Weak and Strong El Niño composites are not correlated $(r=0.17)$. Generally speaking, the Strong events tend to have disproportionately extreme impacts in Texas and Florida, whereas the Weak case impacts tend to be more severe in the Southwest.

\section{b. DJF dynamics}

Figure 6 examines the dynamical signals associated with the composites in Figs. 3-5. The ERSSTv5 anomalies (shading) show the variations in strength between the ENSO event types. The ocean patterns are similar between Weak and Strong La Niñas with only the amplitude in the equatorial Pacific changing. The patterns shift spatially for El Niño; however, only the Strong El Niño events have warming in the eastern Pacific near Ecuador and Peru.

OLR (Lee 2017) is used as a proxy for tropical convection. That convection provides the critical bridge between the equatorial SST anomalies and the extratropical circulation that affects the United States (Chiodi and Harrison 2013). The patterns are generally as expected. Enhanced convection (negative OLR; green contours) occurs over the warm equatorial Pacific SST anomalies during Strong El Niño events (Fig. 6b) with compensating subsidence (positive OLR; brown contours) to the north, south, and west. This pattern is reversed during La Niña. The OLR differences between Weak and Strong La Niña are subtle, but larger differences appear between Weak El Niño and Strong El Niño. Barely any of the OLR anomalies are significant during Weak El Niño, while the full pattern is significant during Strong El Niño. 

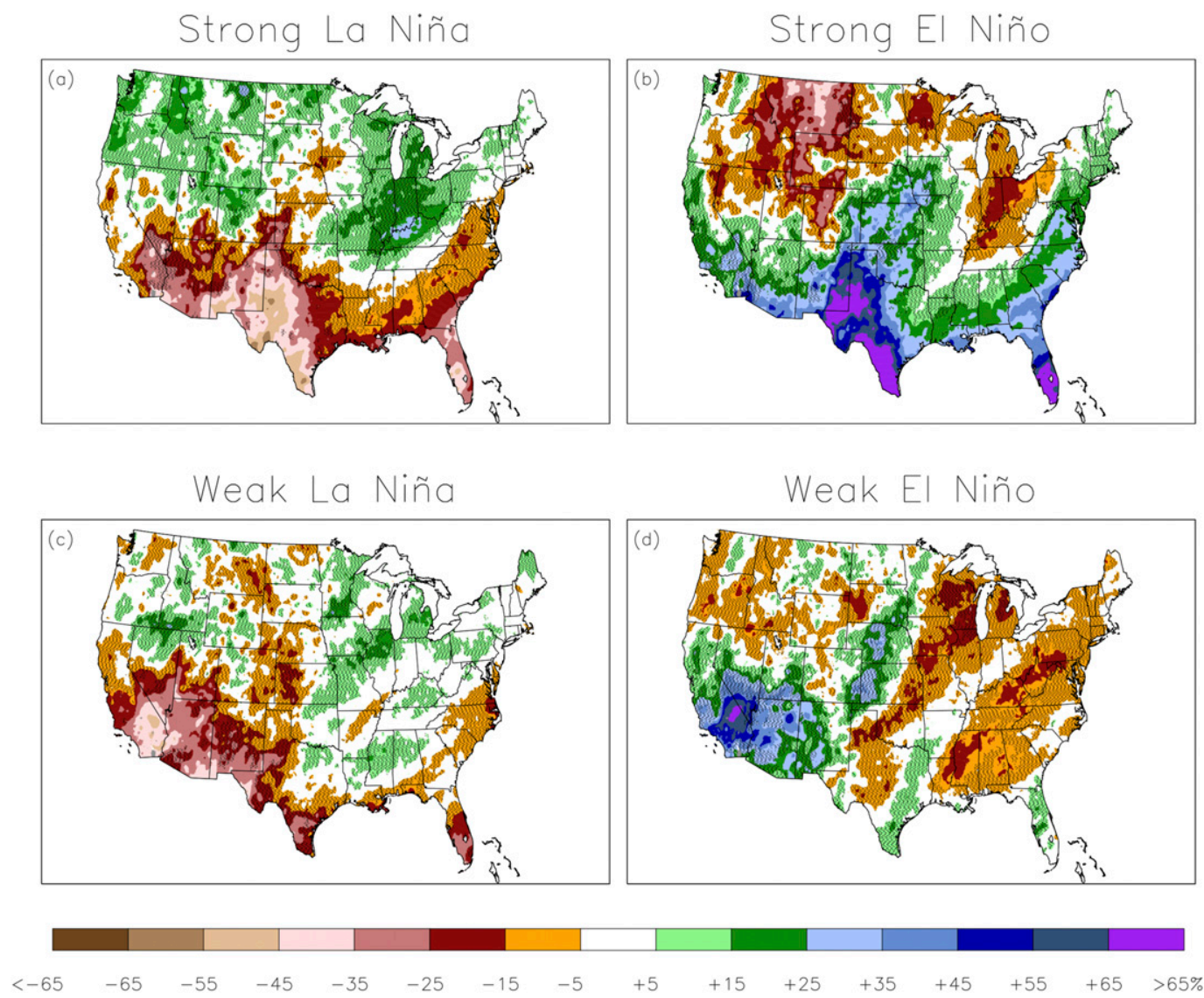

FIG. 5. As in Fig. 3, but for DJF monthly precipitation, reported as percent deviations. Dark gray areas indicate grid cells for which the 15 -yr running mean was equal to zero for at least one 15 -yr period in the period of record.

The 500-hPa geopotential height anomalies (blue/red contours) show the extratropical Rossby wave trains forced by the changes in the SSTs and anomalous convection. This wave train originates with a ridge over the central North Pacific during La Niña and a trough during El Niño. Subtle variations in these features affect the downstream impacts over the United States. Even though the convective anomalies are similar between Weak and Strong La Niña events, the wave train is more robust during Strong events. That difference is consistent with the differences in Figs. 3 and 4. For El Niño, the wave train is again more prominent during Strong events, but it is also shifted eastward relative to the Weak events. That eastward shift places the ridge closer to the northern plains instead of the mountain west, and the trough is over the southeastern United States instead of the Northeast. These differences are consistent with the variations in Tmin and Tmax, which are more northsouth for Strong events and east-west for Weak events (Figs. 3b,d and 4b,d). The trough across the southern
United States during Strong El Niño (Fig. 6b) also suggests a greater enhancement of the subtropical jet, which would also lead to more precipitation there (Fig. 5b).

\section{c. JJA composites}

The composite patterns during JJA are considerably weaker than their DJF counterparts. Interestingly, the most prominent features for both Tmax (Fig. 7) and Tmin (Fig. 8) occur in the upper Midwest in Strong La Niña and in the northern plains in Weak El Niño, but with no strong composite anomalies during Weak La Niña or Strong El Niño. The signals are anticorrelated with each other, with a correlation coefficient of about -0.63 for both Tmax and Tmin. The JJA Prcp composites (Fig. 9) are more active yet less coherent, with the sharpest contrast occurring in California between Strong La Niña and Strong El Niño events, although the associated rainfall deviations in absolute terms are quite low during California summers. In addition, the Strong La Niña precipitation 
(a) Strong La Niña

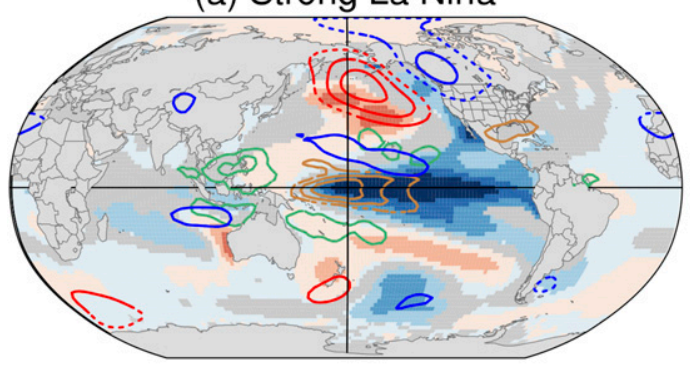

(c) Weak La Niña
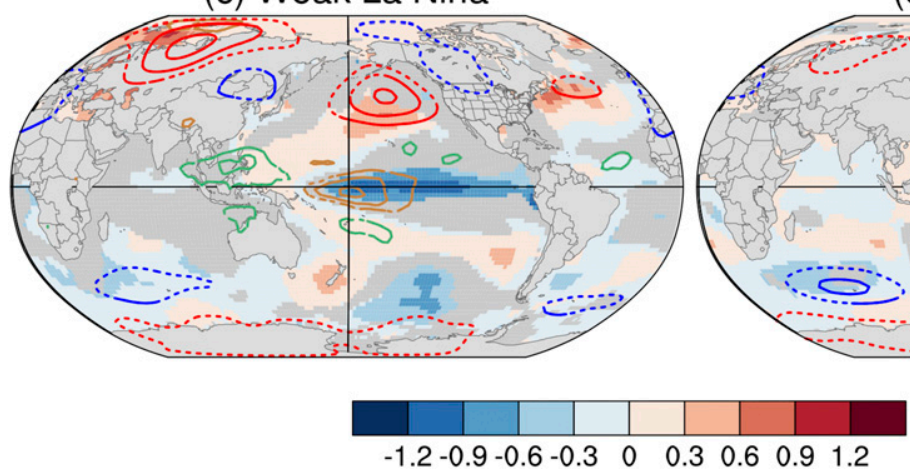

(b) Strong El Niño

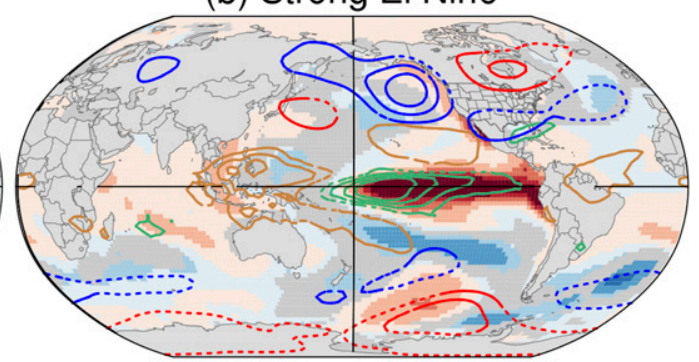

(d) Weak El Niño

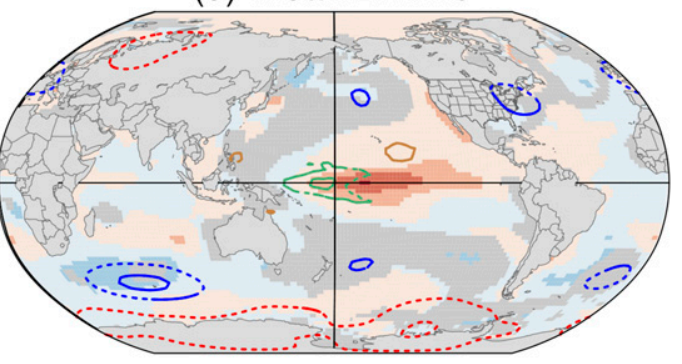

$\operatorname{deg} \mathrm{C}$

FIG. 6. Composite anomalies for DJF ENSO events of ERSSTv5 (shading), monthly OLR (Lee 2017) (green/brown contours), and NCEP-NCAR reanalysis (Kalnay et al. 1996) 500-hPa geopotential heights (blue/red contours). OLR is contoured every $10 \mathrm{~W} \mathrm{~m}^{-2}$ with negative (cloudy) values in green and positive (clear) values in brown. Geopotential height is contoured every $20 \mathrm{~m}$ with positive values in red and negative in blue. Statistical significance is evaluated at the $90 \%$ level using a two-tailed Monte Carlo method following Schreck et al. (2013). Insignificant ERSST values are masked in gray, while insignificant values for the other variables are dashed.

anomalies show a tendency for dryness in the central United States, while the Weak El Niño precipitation anomaly pattern exhibits wetter conditions in this region.

\section{d. JJA dynamics}

Figure 10 shows the dynamical drivers for each of the ENSO phases during JJA. As in the United States composites, the signals in Fig. 10 are considerably weaker than their DJF counterparts. The JJA Weak La Niña composite has only a small area of cool SST anomalies on the Equator that are statistically significant. The Weak El Niño composite has a larger area of significant anomalies, but their amplitude is still very small $\left(<0 \cdot 6^{\circ} \mathrm{C}\right)$. As a result, neither has significant OLR anomalies, let alone significant extratropical circulations, consistent with the weak anomalies in Figs. 7-9. The Strong JJA composites exhibit more of the canonical SST patterns. However, the OLR anomalies are much weaker than in DJF, especially for La Niña. The limited extratropical response is also largely confined to the Southern Hemisphere, which makes sense as that would be the winter hemisphere with stronger extratropical variability. The more localized SST changes in the eastern Pacific do seem to have some impact on western U.S. summer precipitation, possibly through changes in sea level pressure patterns and associated low-level moisture flux patterns.

\section{e. ENSO normals}

In addition to the ENSO composites, we use the most recent OCN to define the ENSO normals. Thus, the ENSO normals are recentered around an operationally updated "alternative" normal that can be appreciably different from the most recent 30 -yr normals. Figure 11 shows the OCN values relative to the corresponding 1981-2010 normals for January. The resulting difference is a proxy for the recent trends. The most prominent temperature signal is a warming in New England in both Tmax and Tmin fields, in addition to somewhat warmer conditions in California and cooler conditions in much of the Midwest. Drier conditions are reported in the Southeast, New England, much of the Great Plains, and California, while somewhat wetter conditions prevail in parts of the Midwest 

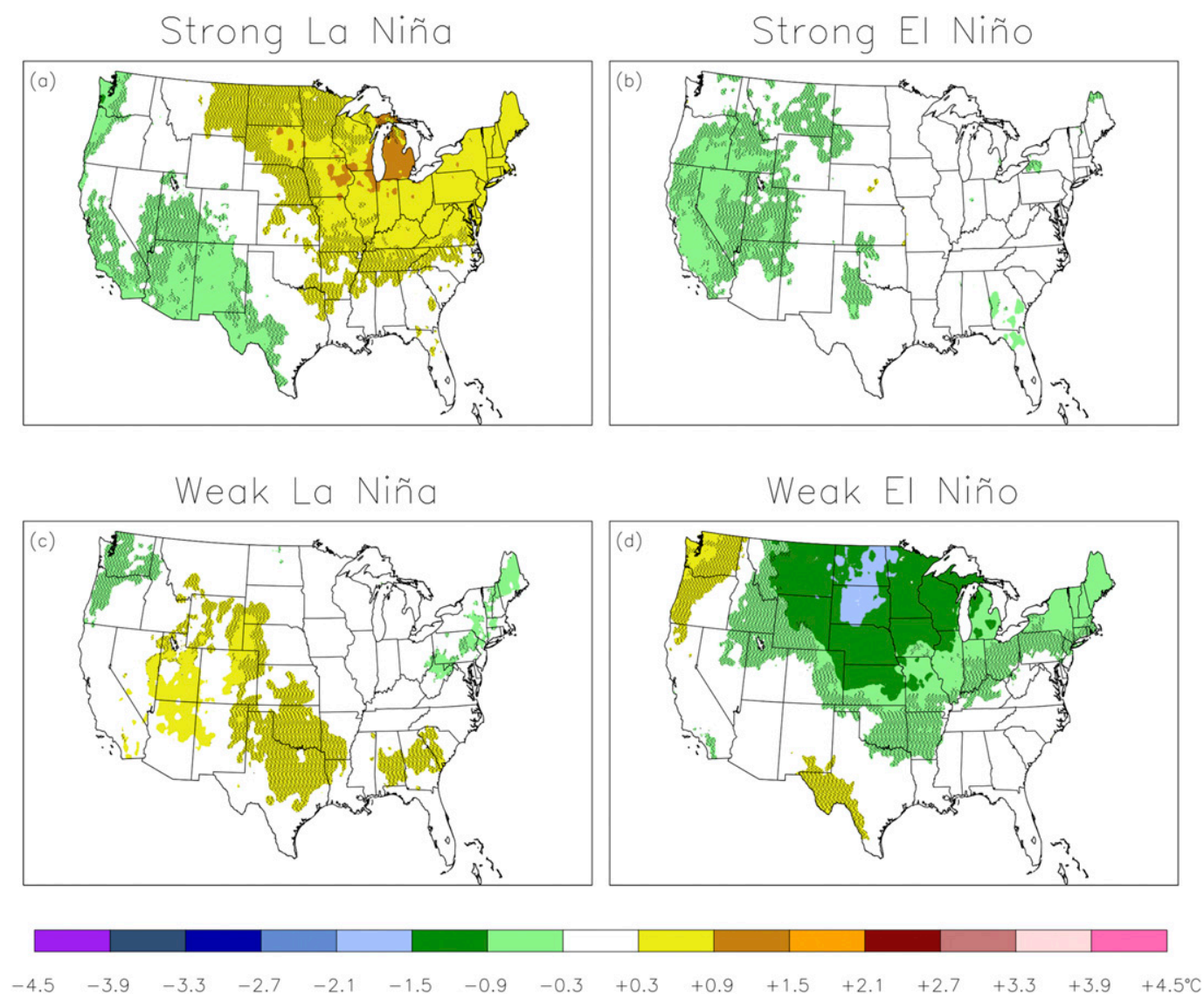

FIG. 7. As in Fig. 3, but for JJA monthly mean maximum temperature.

and Intermountain West. For July (Fig. 12) somewhat warmer conditions cover much of CONUS, whereas drier conditions are found in the Northwest and northern Great Plains and wetter conditions stretching across the southern half of CONUS and into the Northeast.

It is instructive to look at the broad array of parameters that will be available for a single grid cell. Table 3 shows the Tmax, Tmin, and Prcp ENSO normals for January in absolute units of ${ }^{\circ} \mathrm{C}$ and $\mathrm{mm}$ as well as their associated composite mean and quantile anomalies ( ${ }^{\circ} \mathrm{C}$ and percent deviations) for six cities across the CONUS. For Dallas, Texas, the Strong La Niña (Strong El Niño) normal for January Prcp is $56.6 \mathrm{~mm}(83.7 \mathrm{~mm})$, which corresponds to a $-19.6 \%(+18.9 \%)$ deviation from that month's OCN value of $70.4 \mathrm{~mm}$. For Seattle, Washington, the interquartile range (IQR) for Strong El Niño Tmax composites is $0.2^{\circ}-1.9^{\circ} \mathrm{C}$, suggesting a likelihood greater than $75 \%$ of warmer-than-normal conditions. However, the vast majority of IQRs include zero, which, along with the $10 \%$ and $90 \%$ level values, indicates fairly wide ranges of expected values overall. The tabular results for January Tmax in Orlando are also illustrated graphically in Fig. 1. La Niña (El Niño) months clearly tend toward warmer (cooler) conditions as indicated by the observations in Figs. $1 \mathrm{a}-\mathrm{c}$ as well as the resulting quantile levels in Fig. 1d.

\section{Discussion and conclusions}

Climatological normals are indispensable planning tools in a wide variety of industries. Most often, they are used as implicit forecasts of what meteorological conditions may be expected when other methods lack skill. However, the rapid change of our current climate has reduced the already limited skill of traditional 30-yr normals. Following other recent studies (e.g., Huang et al. 1996; Arguez et al. 2013), we implement the optimal climate normal (OCN), which uses a shorter averaging period (10 years for temperature and 15 years for precipitation) to better adapt to the changing climate. After secular climate change, the most predictable component of the climate season is arguably ENSO and its impacts. In 

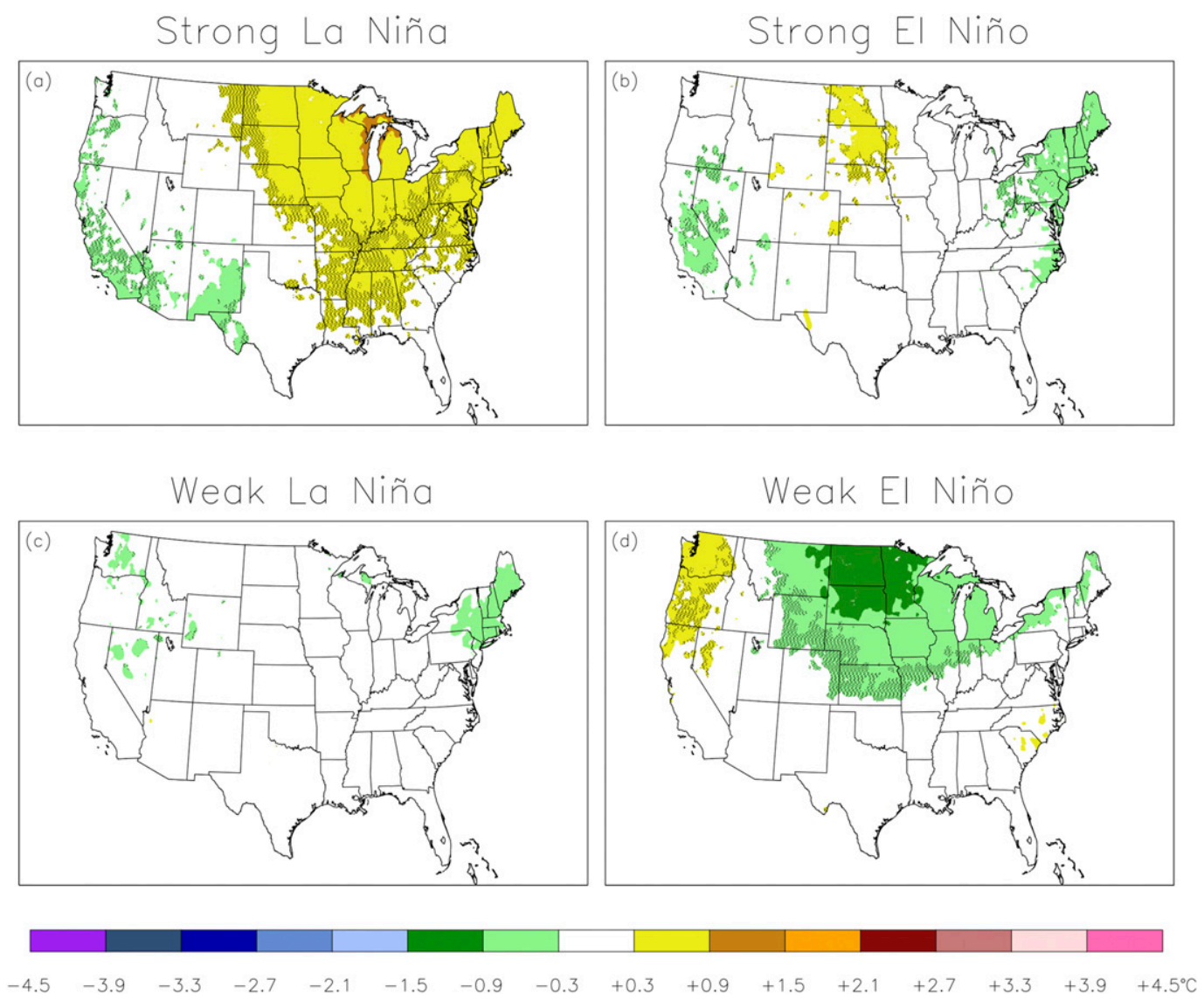

$\begin{array}{llllllllllllllll}-4.5 & -3.9 & -3.3 & -2.7 & -2.1 & -1.5 & -0.9 & -0.3 & +0.3 & +0.9 & +1.5 & +2.1 & +2.7 & +3.3 & +3.9 & +4.5^{\circ} \mathrm{C}\end{array}$

FIG. 8. As in Fig. 3, but for JJA monthly mean minimum temperature.

this study, we add composites of ENSO impacts to the $\mathrm{OCN}$ in order to provide users with a picture of what conditions may look like in our current climate when a particular phase of ENSO occurs. Users may then cross reference these ENSO normals with external forecasts of ENSO to better understand the upcoming climate and make better decisions.

The most critical underpinnings of the ENSO normals are the methods used to identify both the climate change and the ENSO components. Several methods of "alternative" or "experimental" normals have been proposed, including the OCN, hinge-fit, $N$-yr averages, weighted 30-yr averages, and spectral filtering (Livezey et al. 2007; Arguez and Vose 2011; Arguez et al. 2013). We chose the OCN because of its balance of simplicity and skill, including preliminary findings suggesting that updated 10-yr (15yr) averages for temperature (precipitation) performed well as a predictor of future climate conditions using the nClimGrid database (R. Vose 2018, personal communication). We also used the OCN for calculating the anomalies for our ENSO composites, ensuring that the climate change and
ENSO composite components of our analysis are consistent.

For identifying ENSO, we used the widely accepted ONI. More sophisticated ENSO indices exist, some of which might have stronger ties to extratropical impacts in the United States and elsewhere (e.g., Wolter and Timlin 2011; Chiodi and Harrison 2013). However, ONI remains the "official" index used by NOAA for identifying ENSO events (L'Heureux et al. 2018), which lends the authenticity needed for developing a new normals product. Our main deviation from CPC's methodology for identifying events was in the index threshold. CPC uses a fixed $0.5^{\circ} \mathrm{C}$ threshold and does not classify events by strength. However, the impacts of ENSO are known to be related in part to the strength of the events, as confirmed by the results of this study. We also needed to produce ENSO normals for all 12 months, and thus sample size considerations were of critical importance. ENSO has a marked annual cycle, so the $0.5^{\circ} \mathrm{C}$ threshold would have left too few events during the summer months. We instead used two sets of thresholds: 1) the terciles of ONI for each month were used to define El Niño and La Niña 

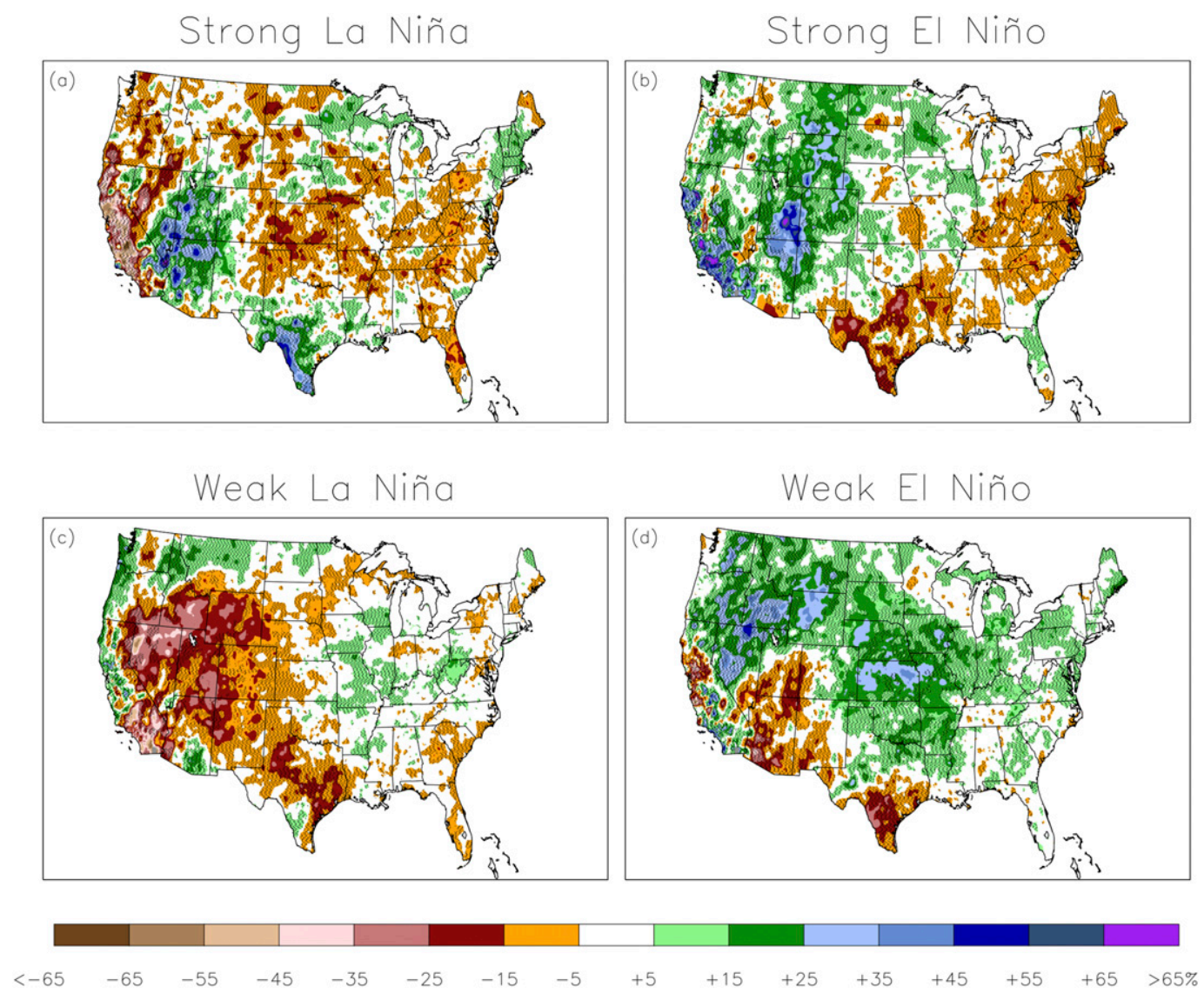

FIG. 9. As in Fig. 5, but for JJA monthly precipitation.

events, and 2) the sextiles (top and bottom one-sixth) were used to differentiate Weak from Strong events. These thresholds come out to approximately $\pm 0.5^{\circ}$ and $\pm 1.0^{\circ} \mathrm{C}$ during the peak winter months (Table 1 ). The strong variations in the composites for Strong and Weak events in this study support the validity of these separations.

An interesting benefit of calculating these ENSO normals has been quantifying the relative contributions of ENSO and secular change. For each month and variable, we calculate the mean absolute value of the La Niña and El Niño composites $(E)$ and compared it to the absolute value of the corresponding climate change contribution $(C)$, as represented by the difference between the OCN value and the 19812010 climate normal (i.e., the values in Figs. 11 and 12 but for all months). The resulting fields (not shown) of $E /(E+C)$ vary a great deal across space and months. Generally, the relative contributions of $E$ and $C$ are comparable in a CONUS-wide-average sense, with a slight tendency toward $C$ for all 3 variables, especially for Tmin. The primary exception to this rule is winter months, for which $E$ is slightly more impactful than $C$ for all 3 variables. Note that the impact of $C$ is a function of the proximity of the last year of the period of record (i.e., 2017) to the end of the previous decade (i.e., 2010). Thus, while these characterizations represent a snapshot of a timedependent relationship, it is clear that both effects need to be accounted for when planning for real-time ENSO impacts.

In addition to the composites and $\mathrm{OCN}$, the quantile values provide users with a realistic range of potential impacts for their locations of interest. Although composites reveal broad areas that are significantly different from zero in a mean sense, the distributions themselves virtually always include at least a few events with anomalies of the opposite sign. Generally speaking, the ranges of potential impacts for precipitation and temperature are rather broad; users of this information need to be aware of this important characteristic of the underlying data.

For example, consider the drier-than-normal wintertime conditions experienced in Southern California during the Strong El Niño event of 2015/16. It was widely 
(a) Strong La Niña

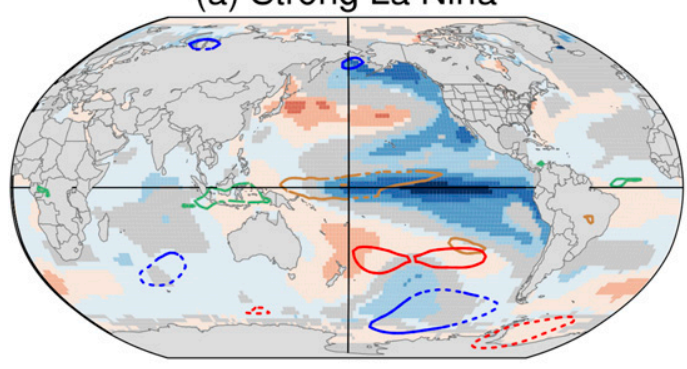

(c) Weak La Niña

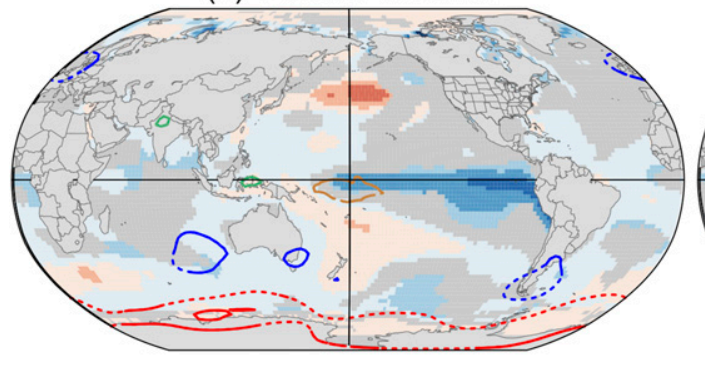

(b) Strong El Niño

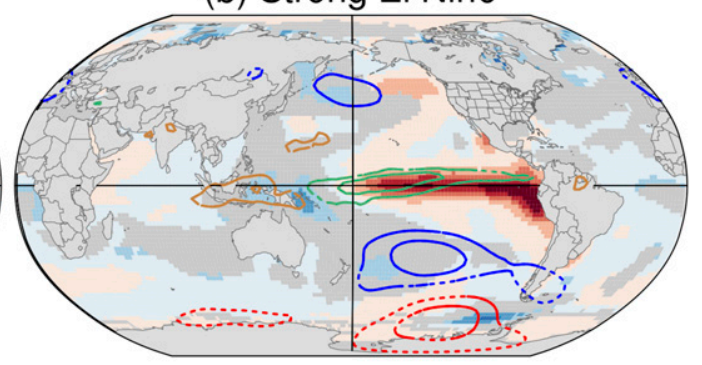

(d) Weak El Niño

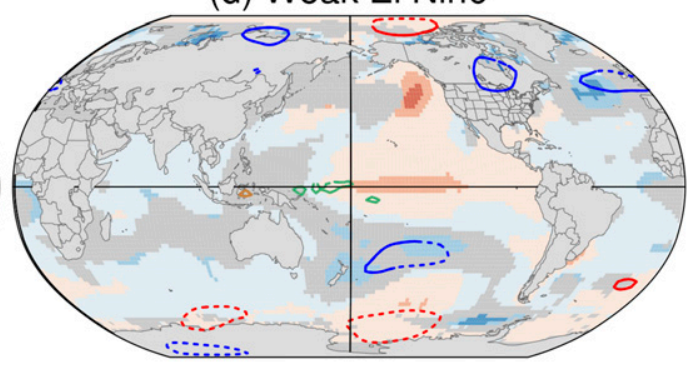

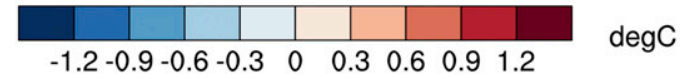

FIG. 10. As in Fig. 6, but for JJA.

expected that this event would bring much-needed relief to Southern California, which was in the midst of a multiyear drought (see Hoell et al. 2016; Siler et al. 2017; Paek et al. 2017). The nClimGrid readings for San Diego $\left(32.7292^{\circ} \mathrm{N}, 117.1458^{\circ} \mathrm{W}\right.$ as in Table 3$)$ for December, January, and February were 27, 82, and $3 \mathrm{~mm}$, respectively. While the seasonal total was $34 \%$ drier than the corresponding ENSO normal total for Strong El Niño events and $18 \%$ drier than the OCN total, the monthly percent deviations relative to the corresponding OCN experienced pronounced swings from $-44 \%$ in December to $+122 \%$ in January to $-94 \%$ in February. While the December value was within the IQR, albeit in the lower end, the January reading was above the IQR yet below the $90 \%$ quantile (see Table 3), and the February reading was well below the $10 \%$ quantile for Strong El Niño events. Importantly, our results indicate that monthly precipitation composites over DJF are not significantly different from zero almost anywhere in California for Strong El Niño or Strong La Niña events (see Fig. 5), whereas virtually all (most) areas of Southern California experience significantly wetter-than-normal (drier than normal) conditions during Weak El Niño (Weak La Niña) events in a composite sense. Furthermore, the seasonal percent deviation value of $-18 \%$ (relative to the OCN total) is wetter than the lower quartile for December, January, and February distributions during Strong El Niño events. Therefore, notwithstanding significant month-to-month swings, our results indicate that the wintertime dryness experienced in Southern California during the Strong El Niño event of 2015/16 was reasonably within the realm of expectation, illustrating one way that our analysis can place observed ENSO-related impacts into a historical perspective.

The variables in this study (Tmin, Tmax, and total precipitation) represent a small subset of those that are often included in traditional normals. Our study was limited by the temporal resolution of the current monthly nClimGrid data. Future extensions of this product suite will be facilitated by a forthcoming daily version of the gridded product. Among the most valuable variables being considered are heating, cooling, and growing degree-days. Counts of threshold days (e.g., Tmax $\geq 32^{\circ} \mathrm{C}$, Tmin $\leq 0^{\circ} \mathrm{C}$, precipitation $\geq 0$ ) would also be feasible, along with estimating climate change and ENSO impacts on the length of the growing season.

Numerous studies have shown that different "flavors" of ENSO, such as the ENSO Modoki (e.g., see Ashok et al. 2007), and/or interactions between ENSO and the Pacific decadal oscillation or the Atlantic multidecadal oscillation (e.g., see McCabe et al. 2004) can lead to varying ENSO-related impacts across the globe. At this time, our period of record is 

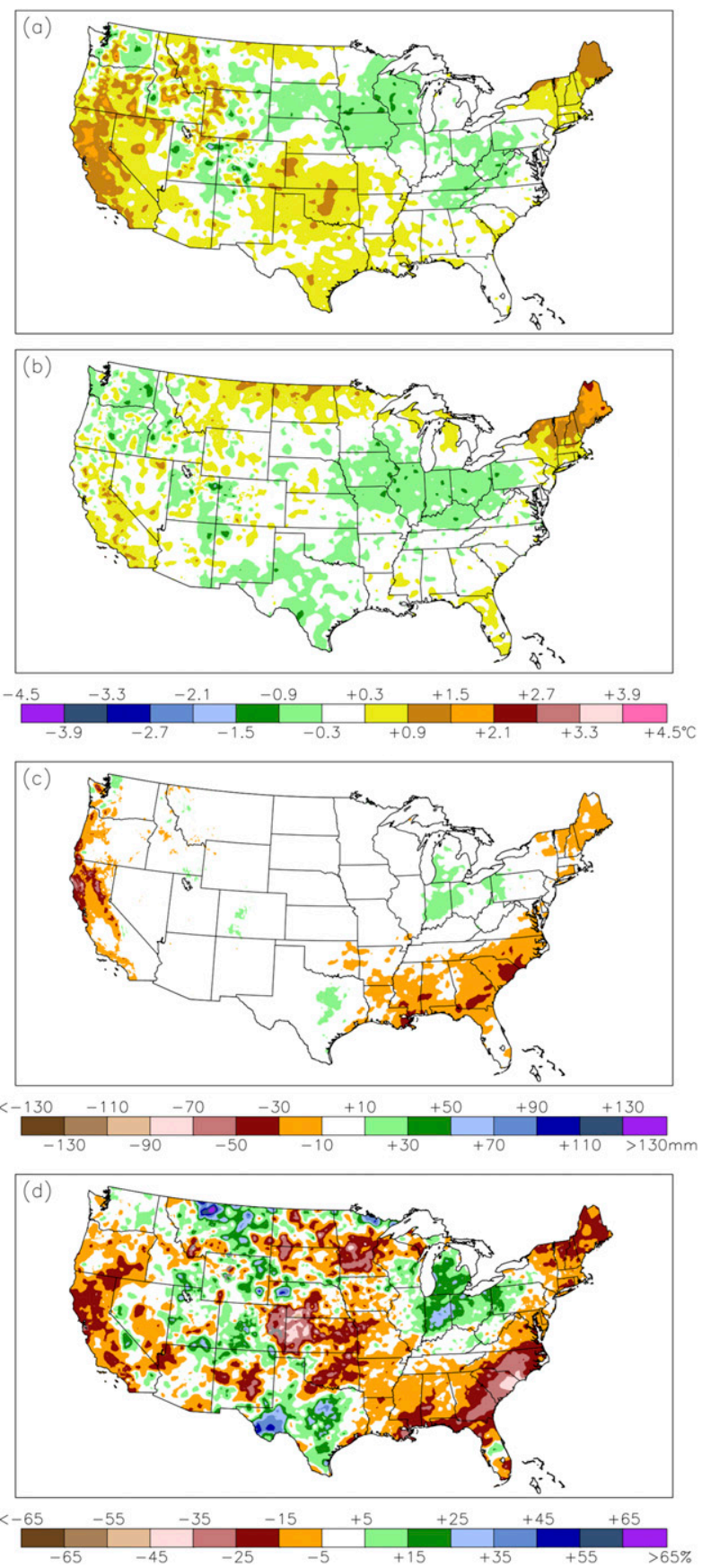

FIG. 11. Differences between the January OCN and the corresponding 1981-2010 normal for (a) mean monthly maximum temperature $\left({ }^{\circ} \mathrm{C}\right)$, (b) mean monthly minimum temperature $\left({ }^{\circ} \mathrm{C}\right)$, and $(\mathrm{c})$ monthly precipitation $(\mathrm{mm})$. Temperature OCN are computed over 2008-17 and precipitation OCN are computed over 2003-17. (d) As in (c), but reported as a percent deviation relative to the January OCN. Areas shaded in dark gray indicate grid cells for which the OCN and/or the 19812010 normal was less than $5 \mathrm{~mm}$.
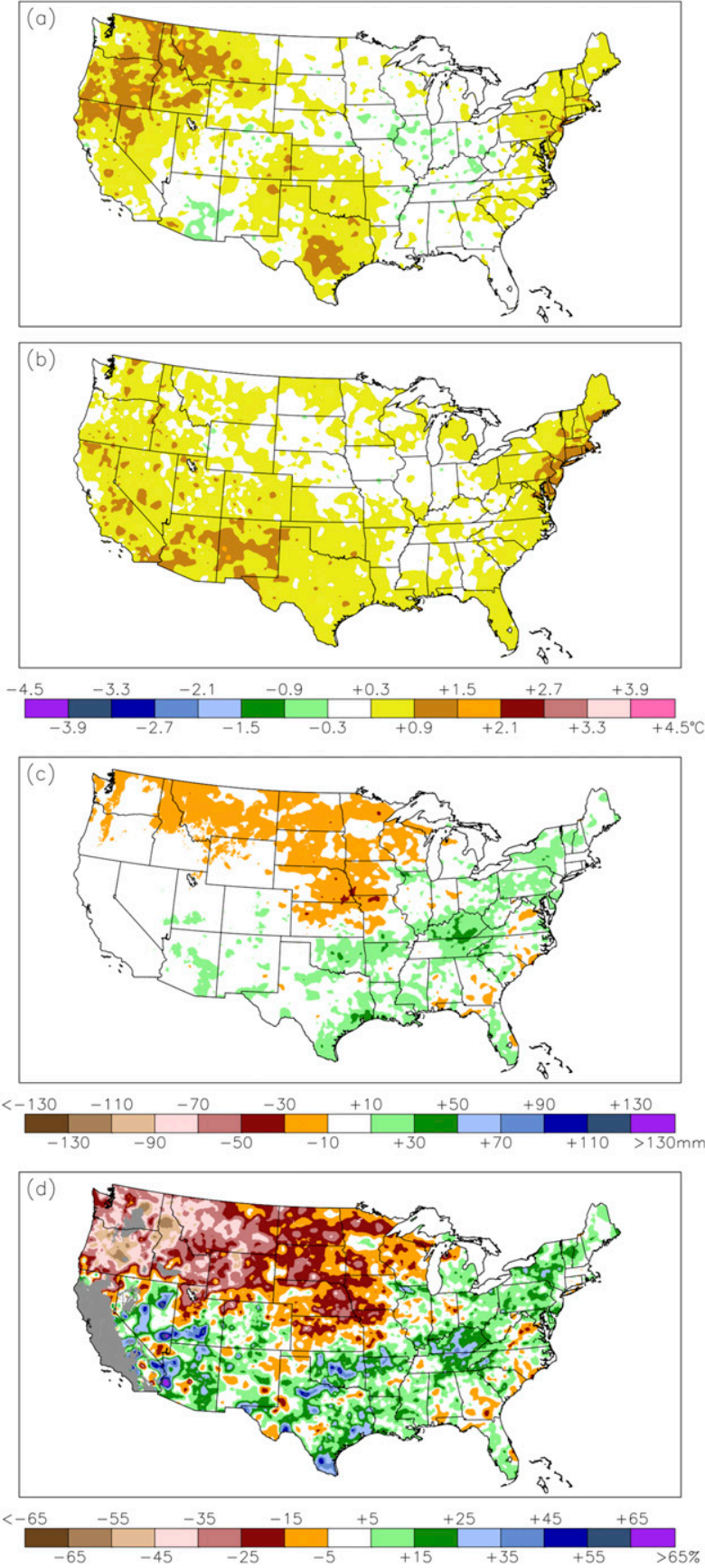

FIG. 12. As in Fig. 11, but for July.

not sufficiently long enough to further stratify our composites by ENSO types or multidecadal influences; the inability to account for these important factors is the primary limitation of this new product line. However, it would be worthwhile to pursue future work on the feasibility of further stratification, especially as additional ENSO events are added to the record. 


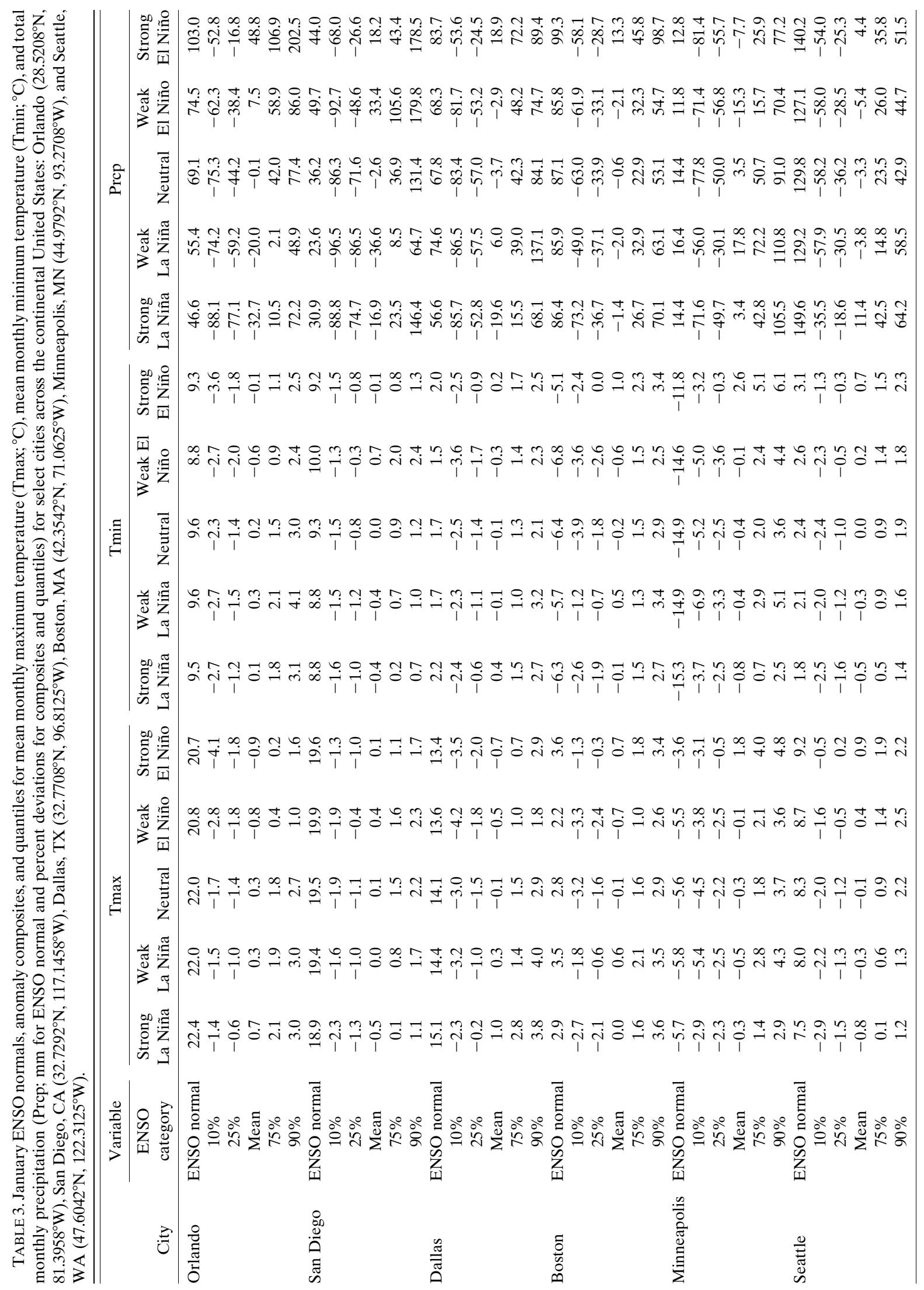


Acknowledgments. The authors kindly acknowledge Michelle L'Heureux for fruitful discussions on the methodology employed and Carrie Morrill for thoughtful comments on an earlier version of this manuscript. Inamdar and Schreck were supported by NOAA through the Cooperative Institute for Climate and Satellites-North Carolina under Cooperative Agreement NA14NES432003.

\section{REFERENCES}

AgroClimate, 2016: Climatology. Southeast Climate Consortium, http://agroclimate.org/tools/climatology/.

Arguez, A., and R. S. Vose, 2011: The definition of the standard WMO climate normal: The key to deriving alternative climate normals. Bull. Amer. Meteor. Soc., 92, 699-704, https://doi.org/ 10.1175/2010BAMS2955.1.

_,$-\ldots$, and J. Dissen, 2013: Alternative climate normals: Impacts to the energy industry. Bull. Amer. Meteor. Soc., 94, 915-917, https://doi.org/10.1175/BAMS-D-12-00155.1.

Ashok, K., S. K. Behera, S. A. Rao, H. Weng, and T. Yamagata, 2007: El Niño Modoki and its possible teleconnection. J. Geophys. Res., 112, C11007, https://doi.org/10.1029/2006JC003798.

Barnston, A. G., and C. F. Ropelewski, 1992: Prediction of ENSO episodes using canonical correlation analysis. J. Climate, 5, 1316-1345, https://doi.org/10.1175/1520-0442(1992)005<1316: POEEUC $>2.0 . \mathrm{CO} ; 2$.

—_, M. Chelliah, and S. B. Goldenberg, 1997: Documentation of a highly ENSO-related SST region in the equatorial Pacific. Atmos.-Ocean, 35, 367-383, https://doi.org/10.1080/ 07055900.1997 .9649597$.

Chiodi, A. M., and D. E. Harrison, 2013: El Niño impacts on seasonal U.S. atmospheric circulation, temperature, and precipitation anomalies: The OLR-Event perspective. J. Climate, 26, 822837, https://doi.org/10.1175/JCLI-D-12-00097.1.

CPC, 2012: ENSO temperature and precipitation composites. NOAA, accessed 1 June 2018, https://www.cpc.ncep.noaa.gov/products/ precip/CWlink/ENSO/composites/.

__ 2018: Cold \& warm episodes by season. NOAA, accessed 1 June 2018, http://origin.cpc.ncep.noaa.gov/products/analysis_ monitoring/ensostuff/ONI_v5.php.

Daly, C., M. Halbleib, J. I. Smith, W. P. Gibson, M. K. Doggett, G. H. Taylor, J. Curtis, and P. A. Pasteris, 2008: Physiographically sensitive mapping of temperature and precipitation across the conterminous United States. Int. J. Climatol., 28, 2031-2064, https://doi.org/10.1002/joc.1688.

Dourte, D. R., E. Gelcer, O. Uryasev, C. G. Staub, D. D. Barreto, and C. W. Fraisse, 2017: Gridded, monthly rainfall and temperature climatology for El Niño Southern Oscillation impacts in the United States. Int. J. Climatol., 37, 2200-2208, https:// doi.org/10.1002/joc.4820.

Durre, I., M. J. Menne, B. E. Gleason, T. G. Houston, and R. S. Vose, 2010: Comprehensive automated quality assurance of daily surface observations. J. Appl. Meteor. Climatol., 49, 1615-1633, https://doi.org/10.1175/2010JAMC2375.1.

Fan, Y., and H. van den Dool, 2008: A global monthly land surface air temperature analysis for 1948-present. J. Geophys. Res., 113, D01103, https://doi.org/10.1029/2008JG000723.

Guo, Y.-Y., M. Ting, Z. Wen, and D. E. Lee, 2017: Distinct patterns of tropical Pacific SST anomaly and their impacts on North American climate. J. Climate, 30, 5221-5241, https://doi.org/ 10.1175/JCLI-D-16-0488.1.
Hoell, A., M. Hoerling, J. Eischeid, K. Wolter, R. Dole, J. Perlwitz, T. Xu, and L. Cheng, 2016: Does El Niño intensity matter for California precipitation? Geophys. Res. Lett., 43, 819-825, https://doi.org/10.1002/2015GL067102.

Horel, J. D., and J. M. Wallace, 1981: Planetary-scale atmospheric phenomena associated with the Southern Oscillation. Mon. Wea. Rev., 109, 813-829, https://doi.org/10.1175/15200493(1981)109<0813:PSAPAW > 2.0.CO;2.

Huang, J., H. M. van den Dool, and A. G. Barnston, 1996: Longlead seasonal temperature prediction using optimal climate normals. J. Climate, 9, 809-817, https://doi.org/10.1175/15200442(1996)009<0809:LLSTPU > 2.0.CO;2.

Huang, B., and Coauthors, 2017: Extended Reconstructed Sea Surface Temperature, version 5 (ERSSTv5): Upgrades, validations, and intercomparisons. J. Climate, 30, 8179-8205, https://doi.org/10.1175/JCLI-D-16-0836.1.

Ji, M., D. W. Behringer, and A. Leetmaa, 1998: An improved coupled model for ENSO prediction and implications for ocean initialization. Part II: The coupled model. Mon. Wea. Rev., 126, 1022-1034, https://doi.org/10.1175/1520-0493(1998)126<1022: AICMFE $>2.0 . \mathrm{CO} ; 2$.

Johnson, N. C., 2013: How many ENSO flavors can we distinguish? J. Climate, 26, 4816-4827, https://doi.org/10.1175/JCLI-D-1200649.1.

Kalnay, E., and Coauthors, 1996: The NCEP/NCAR 40-Year Reanalysis Project. Bull. Amer. Meteor. Soc., 77, 437-471, https:/ doi.org/10.1175/1520-0477(1996)077<0437:TNYRP > 2.0.CO;2.

L'Heureux, M., G. D. Bell, and M. S. Halpert, 2018: ENSO and the tropical Pacific [in "State of the Climate in 2017']. Bull. Amer. Meteor. Soc., 99, S102-S104, https://journals.ametsoc.org/doi/ pdf/10.1175/2018BAMSStateoftheClimate.1.

Lee, H.-T., 2017: Outgoing longwave radiation (OLR)Monthly. NOAA's Climate Data Record Program Climate Algorithm Theoretical Basis Doc. CDRP-ATBD0097, 46 pp., https://www1.ncdc.noaa.gov/pub/data/sds/ cdr/CDRs/Outgoing \%20Longwave \%20Radiation \% 20-\% 20Monthly/AlgorithmDescription_01B-06.pdf.

Livezey, R. E., K. Y. Vinnikov, M. M. Timofeyeva, R. Tinker, and H. M. van den Dool, 2007: Estimation and extrapolation of climate normals and climatic trends. J. Appl. Meteor. Climatol., 46, 1759-1776, https://doi.org/10.1175/2007JAMC1666.1.

Mann, M. E., 2004: On smoothing potentially non-stationary climate time series. Geophys. Res. Lett., 31, L07214, https://doi.org/ 10.1029/2004GL019569.

McCabe, G. J., M. A. Palecki, and J. L. Betancourt, 2004: Pacific and Atlantic Ocean influences on multidecadal drought frequency in the United States. Proc. Natl. Acad. Sci. USA, 101, 4136-4141, https://doi.org/10.1073/pnas.0306738101.

Menne, M. J., and C. N. Williams Jr., 2009: Homogenization of temperature series via pairwise comparisons. J. Climate, 22, 1700-1717, https://doi.org/10.1175/2008JCLI2263.1.

—, I. Durre, R. S. Vose, B. E. Gleason, and T. G. Houston, 2012: An overview of the Global Historical Climatology NetworkDaily Database. J. Atmos. Oceanic Technol., 29, 897-910, https://doi.org/10.1175/JTECH-D-11-00103.1.

Mo, K. C., 2010: Interdecadal modulation of the impact of ENSO on precipitation and temperature over the United States. J. Climate, 23, 3639-3656, https://doi.org/10.1175/2010JCLI3553.1.

Paek, H., J. Y. Yu, and C. Qian, 2017: Why were the 2015/2016 and 1997/1998 extreme El Niños different? Geophys. Res. Lett., 44, 1848-1856, https://doi.org/10.1002/2016GL071515.

Rasmusson, E. M., and T. H. Carpenter, 1982: Variations in tropical sea surface temperature and surface wind fields associated 
with the Southern Oscillation/El Niño. Mon. Wea. Rev., 110, 354-384, https://doi.org/10.1175/1520-0493(1982)110<0354: VITSST $>2.0 . \mathrm{CO} ; 2$.

Ropelewski, C. F., and M. S. Halpert, 1986: North American precipitation and temperature patterns associated with the El Niño/ Southern Oscillation (ENSO). Mon. Wea. Rev., 114, 2352-2362, https://doi.org/10.1175/1520-0493(1986)114<2352. NAPATP $>2.0 . \mathrm{CO} ; 2$.

—_, and ——, 1987: Global and regional scale precipitation patterns associated with the El Niño/Southern Oscillation. Mon. Wea. Rev., 115, 1606-1626, https://doi.org/10.1175/15200493(1987)115<1606:GARSPP>2.0.CO;2.

— , and -1989 : Precipitation patterns associated with the high index phase of the Southern Oscillation. J. Climate, 2 , 268-284, https://doi.org/10.1175/1520-0442(1989)002<0268: PPAWTH $>2.0 . \mathrm{CO} ; 2$.

— , and — 1996: Quantifying Southern Oscillation-precipitation relationships. J. Climate, 9, 1043-1059, https://doi.org/10.1175/ 1520-0442(1996)009<1043:QSOPR >2.0.CO;2.

Schreck, C. J., L. Shi, J. P. Kossin, and J. J. Bates, 2013: Identifying the MJO, equatorial waves, and their impacts using 32 years of HIRS upper-tropospheric water vapor. J. Climate, 26, 1418-1431, https://doi.org/10.1175/JCLI-D12-00034.1.

Siler, N., Y. Kosaka, S.-P. Xie, and X. Li, 2017: Tropical ocean contributions to California's surprisingly dry El Niño of
2015/16. J. Climate, 30, 10 067-10 079, https://doi.org/10.1175/ JCLI-D-17-0177.1.

Trenberth, K. E., 1997: The definition of El Niño. Bull. Amer. Meteor. Soc., 78, 2771-2777, https://doi.org/10.1175/1520-0477(1997) $078<2771$ :TDOENO $>2.0 . \mathrm{CO} ; 2$.

van Loon, H., and R. A. Madden, 1981: The Southern Oscillation. Part I: Global associations with pressure and temperature in northern winter. Mon. Wea. Rev., 109,1150-1162, https://doi.org/ 10.1175/1520-0493(1981)109<1150:TSOPIG > 2.0.CO;2.

Vose, R. S., and Coauthors, 2014: Improved historical temperature and precipitation time series for U.S. climate divisions. J. Appl. Meteor. Climatol., 53, 1232-1251, https://doi.org/ 10.1175/JAMC-D-13-0248.1.

Walker, G. T., and E. W. Bliss, 1932: World Weather V. Mem. Roy. Meteor. Soc., 4 (36), 53-84.

- and - 1937: World Weather VI. Mem. Roy. Meteor. Soc., 4 (39), 119-139.

Wilks, D. S., and R. E. Livezey, 2013: Performance of alternative "normals" for tracking climate changes, using homogenized and nonhomogenized seasonal U.S. surface temperatures. J. Appl. Meteor. Climatol., 52, 1677-1687, https://doi.org/ 10.1175/JAMC-D-13-026.1.

Wolter, K., and M. S. Timlin, 2011: El Niño/Southern Oscillation behaviour since 1871 as diagnosed in an extended multivariate ENSO index (MEI.ext). Int. J. Climatol., 31, 1074-1087, https://doi.org/10.1002/joc.2336. 